\title{
The Cultural Cold War and the Circulation of World Literature
}

\section{Insights from Franklin Book Programs in Tehran}

\author{
Esmaeil Haddadian-Moghaddam \\ University of Leuven \\ esmaeil.haddadianmoghaddam@kuleuven.be
}

\begin{abstract}
Historians of the Cold War are often quick to dismiss the role of books and translation programs of the era as propaganda. To contest this, we combine insights from cultural Cold War studies, Translation Studies and World Literature, illustrating the circulation of books and world literature through a Cold War book program. Documentary evidence from the Franklin Book Programs indicate that although Franklin men were engaged in a soft mode of promoting American culture and values, they were not simply Cold War warriors nor was the program a pure propaganda project. The complexity of obtaining and negotiating copyright, the various roles of the local Franklin men and the program's impact on translation and on publishing contest a propagandist reading. Interdisciplinary research on the impact and legacy of the Franklin Book Programs in a non-aligned context can contribute to a better understanding of the global patterns of the circulation of world literature in their local manifestations.
\end{abstract}

\section{Keywords}

the cultural Cold War - Franklin Book Programs - world literature - circulation copyright

\section{Introduction}

Of those factors which affect the circulation of literary works around the world (Sapiro), political factors play a major role. Generally, we know more about such factors during the cultural Cold War in the Western context (Saunders; 
Krabbendam \& Scott-Smith; Cull) than in a non-aligned context, which has only recently received some attention (Vu \& Wongsurawat; Iber; Philips). Yet, research on the book programs of the period in the Middle Eastern parts of the non-aligned context is rare.

Though some book programs such as the Low-Priced books (Barnhisel "Cold Warriors") in the West and Franklin Book Programs in the non-aligned context had implicit political purposes, they contributed to the formation and/or circulation of books and world literature in new contexts. ${ }^{1}$ While this has been under-studied, historians of the Cold War have been quick to dismiss the role of books and translation programs of the era as propaganda. A more complicated image nevertheless emerges from the non-aligned context, where locals transform propaganda into something different in nature, distancing them from cultural relation models of the time. To illustrate this and to complicate the propaganda reading of such programs, this essay will examine Franklin Book Programs focusing on its office in Tehran, Iran (Franklin/Tehran hereafter).

What is reported here is part of a research project about Franklin Book Programs viewed from the prism of Translation Studies, World Literature and cultural Cold War studies with three aims: firstly, to explore the circulation of books and world literature for a period of about three decades in the nonaligned context; secondly, to understand better the impact of this specific form of circulation on the field of cultural production; thirdly, to complicate the propaganda reading of the Franklin Book Programs, from which it follows that Franklin men (i.e. editors, translators working for or with Franklin offices and the directors running them) were simple Cold War warriors.

The examples chosen demonstrate that although Franklin men were engaged in a soft mode of promoting American culture and values, they were not simple Cold War warriors nor was Franklin a purely propaganda program for several reasons. For a start, the complexity of obtaining and negotiating copyright from otherwise commercial publishers not only affects the specifics of selection, but lies at the heart of Franklin's operation. Local Franklin men played various roles of the running of the program, and the program had an impact on translation and on publishing in the said context.

Data were collected from the Franklin archival materials available at the Harry Ransom Center, that is, the correspondence files between the head office in New York (Franklin/New York hereafter) and the field offices mainly in Iran and to some extent in Egypt for the purpose of comparison. Franklin field

1 In this paper, the capitalized form of World Literature refers to the academic field of study, whereas the lower-case refers to the phenomenon. 
offices, extending from Jakarta to Buenos Aires, were located in those nonaligned countries where the impact of the cultural Cold War until recently has received little attention. What is more, in view of cross-cultural models informed by Translation Studies and World Literature scholarship, we need to know more about what could be the most distinctive aspect of such a study, that is, the recipient side, the role and position of the locals vis-à-vis the sender side. It is hoped to shed fresh insights on the global pattern of the circulation of books and world literature and on how the latter is locally construed, canonized or otherwise rejected.

\section{Common Grounds}

Questions about translation, the formation and circulation of world literature beyond their origins interest scholars of both Translation Studies and literary studies. Franco Moretti draws on the economic theories of Immanuel Wallerstein and asserts that the movement of ideas and texts are similar to the movement of goods from the core (Western Europe) to the semi-periphery and periphery (i.e. rest of Europe and the rest of the world, respectively). On this map, some points are privileged (e.g. Paris up to the 196os, as seen by Casanova) and some look forward to becoming "shifting local points" (Thomsen). The points here hardly extend beyond Europe (London, Berlin or Vienna) and the us (New York). As such, a good deal of discussion about World Literature is a reaction to this division in an attempt to pin more signposts on the map or to move them around, in the light of globalization (see Chapter 8 in D'haen). Still, in view of the sustained interest in sociological approaches to translation, favourite players can be identified in this "who's who" game: familiar terms such as translator, editor, publisher and the like have been collectively termed agents of translation (Milton and Bandia) to account for various individuals or institutions that come between the producer and consumer of translations.

An offshoot of Cold War history, the cultural Cold War is the study of various strategies, programs, and policies of the victorious powers after WWII in countering each other through a virtual war (e.g. see Saunders). Cultural diplomacy, "the exchange of ideas, information, value systems, traditions, beliefs and other aspects of culture among nations and their peoples in order to foster mutual understanding" (Cummings, in Barnhisel and Turner 188), is a key term in this line of research (see e.g. Masey \& Lloyd Morgan; Wulf). ${ }^{2}$ For example, there

2 For a study of propaganda and culture during the Cold War, see Hixon; for an interesting 
are valuable insights about the role of print and propaganda during this period (Barnhisel and Turner) and about modernism becoming a pro-Western propaganda tool during the first decade of the Cold War in the us (Barnhisel Cold War). Most of these studies, however, are limited in their scope and only focus on American and European contexts.

Thus, interdisciplinarity in exploring the literary dimensions of the Cold War is necessary. We need more insight from scholars of book history, publishing, and cultural Cold War studies. For example, works inspired by Pierre Bourdieu's sociology of culture (e.g. Thompson) are illuminating, as are studies that explore cultural relations models of the 1950s (e.g. Ninkovich) and later in the Western and Eastern blocs. The sustained interest in the sociology of translation, in particular, the "agent-grounded research" path (Buzelin) is relevant to the study of the actual peoples and their practices in the cultural Cold War. Of equal interest is the relation between ideology and politics of translation (Baumgarten). Lastly, the focus in World Literature on literary works, on circulation, and on translations is equally beneficial to the inquiry.

\section{Franklin Book Programs}

Franklin Publications Inc. (Franklin Book Programs Inc. after 1964) was founded in $195^{2}$ as a non-profit organization. Franklin was initially funded by the us government, but it also relied on donations, private sponsors and its actual operations. In the five years ending 30 June 1963 , "about $35 \%$ of the support came from the us government and the balance from private foundation, individuals, and corporations, from foreign governments and organizations, and from operational income" (Smith, no. 4359, 15 Jan. 1964). In 1974-5, only 10 percent of the funding of a $\$ 14$ million budget was received from us government contracts (Filstrup 432). Franklin's objective reads as follows:

Through the publication and dissemination of the printed word to the peoples of the world outside the United States and its territories, to stimulate interest in and to promote the freedom, dignity and welfare of mankind; and to convey to them the knowledge and information relat-

study focusing on one individual's role in the American Cold War in Europe, see Berghahn; for a study of the Cold War from a mainly political perspective in the Middle East, see Sayigh and Shlaim; for an insightful study of Iran during the period, see Alvandi. For the role of books during WWII, see Loss. 


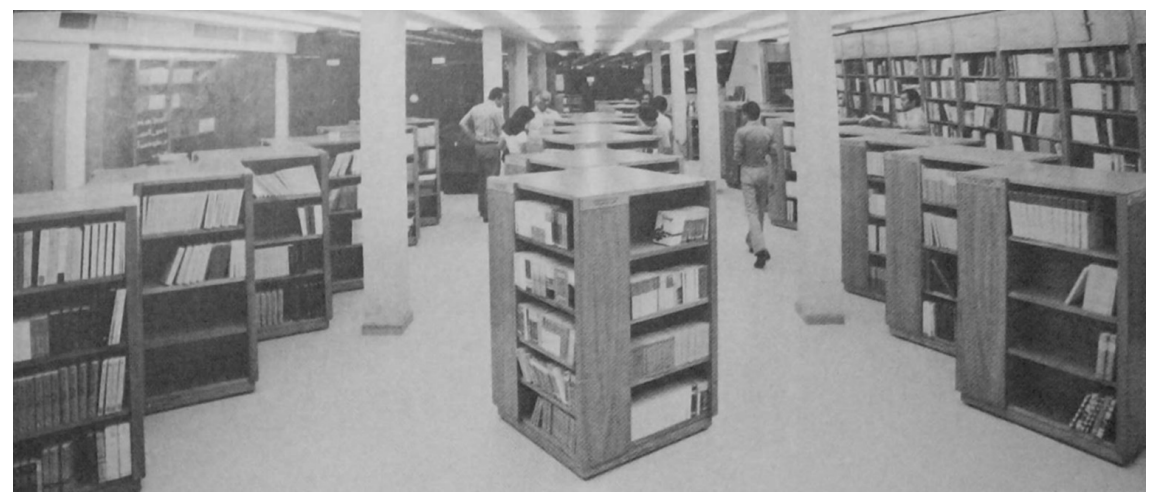

FIGURE 1 Franklin fourth model "Jibi" (pocketbook) bookstore completed in Tehran in mid-1974 FRANKLIN BOOK PROGRAMS INC., 1976

ing to the peoples of the United States, and to stimulate interest in the history, government, culture, economy, technology, science and learning of the people of the United States. The corporation is organized and shall conduct its affairs solely for the purposes aforesaid and not for pecuniary profit.

Franklin Certificate of Incorporation, 29 May $195^{2}$

Franklin thus set out to help the translation of mainly American books into languages of developing countries of the Middle East, Asia, Africa, and Latin America, and where necessary, to create, book-publishing capacity in these countries. In theory, Franklin fitted the American cultural relations model of the 1950s: to promote American books (and values) using the rhetoric of philanthropy and development.

Franklin's head office was in New York with field offices in Egypt (Cairo), Iran (Tehran and for some years in Tabriz), Iraq (Baghdad), Pakistan (Lahore), Afghanistan (Kabul), Bangladesh (Dacca), Lebanon (Beirut), Malaysia (Kuala Lumpur), Indonesia (Djakarta), Nigeria (Lagos, Enugu and Kaduna) Argentina (Buenos Aires) and Brazil (Rio de Janeiro and São Paulo). Books published with the support of Franklin appeared in Arabic, Persian, Urdu, Bengali, Malay and Indonesian, Spanish, Portuguese, English, Yoruba, Hausa and Igbo. Franklin's network was global and relied on the latest communication technologies of the time, from telegrams to telephone and airmail.

Franklin's common operating principles were: books were selected by local people, the staff in each operating office were locals, Franklin was not a publisher, that is, books were published by local publishers and books were for sale not for giving away. Franklin men were very cautious in selecting. We read 
in a 1956 memorandum that, "any attempt by Americans to make up a list of hard-hitting pro-American or anti-communist books would be immediately self-defeating" (13). ${ }^{3}$ Similarly, in setting the price for books, it had to be within the range of local standards: "to go above that range would inhibit sales, and to go below it would invite suspicion and resentment as well as charges of 'dumping'" (9).

Franklin's output was not limited to translation. Gradually, emphasis shifted from mainly translation to publication and preparation of textbooks and audiovisual materials, book-industry training programs for publishers and textbook editors, printing plant projects and mass-distribution projects (mainly in Iran, see Figure 1). It was also actively engaged in international book fairs and scientific seminars related to books, development and often translation. Franklin was dissolved in 1979 after twenty-six years of operation.

In both Cairo and Tehran, the first and second field offices, the reception of Franklin books was generally favorable. For example, the renowned Egyptian author Taha Hossein believed "regardless of the sale aspects, Franklin should take care to promote American books of literary value and that a man like himself who did not speak English should not read Faulkner and Hemingway in French, but rather in Franklin-translated books" (el-Aroussy, no. 408, March 14, 1955). However, the Al Gamhoria journalist Samy Dawood did not share this enthusiasm. He argued that Franklin/Cairo quality publications might be American propaganda. Recalling the story of an Egyptian peasant who refused to take his doctor's medicine at the cost of his life-the peasant preferred the medicine of the "wandering quack doctor" of the village who was absent at the time-Dawood went on to say that he did not see any "difference between the cheap American pills and the propaganda books and magazines which America insists on publishing in our country at cheap prices" (translation from Arabic by Hassan el-Aroussy, director of Franklin/Cairo). El-Aroussy saw the critic's opinion "flimsy," adding: "It is true that our books are cheap if we look at the matter in light of what used to happen in the past when a book that cost only 20 piasters was sold for two pounds ... our books, on the contrary range between eight and eighty piasters ..." (Al Gamhoria November 2, $1955) \cdot^{4}$

3 Cf. Smith in a letter to Sanati, the director of Franklin/Tehran: “... a book by an American and in praise of America may seem entirely unsuitable for your list ..." (Smith, no. 298, February 28, 1961).

4 Dawood's discourse is informed by anti-imperialism and nationalism. He strongly opposed the publication of Arabic editions of foreign periodicals: "They do not convey to us any culture or science or thought. On the contrary, they are mere political organs published for 
Franklin's global dimension and impact has not been empirically studied. Previous research, mainly by Western scholars, has been limited in its scope and theoretical perspectives, and has hardly analyzed Franklin in its local manifestations. Some American historians look at Franklin unidirectionally, overlooking the fact that in any simple communication model there are at least two sides. Because the cause (combatting the threat of communism) did not presumably produce the desired effect (winning hearts and minds around the world), the whole project is reduced either to "propaganda" (Travis 197), or at best a "warning" for the us government to avoid similar mistakes (Laugesen 141). For Travis, the careful selection of Franklin members and the "cozy" patronage of the Iranian royal family are signs of "an amalgamation of sentiments and practices," resulting in only one thing: "propaganda" (197). Another American scholar and librarian summarizes the American "mistake" with a metaphor: "that 'bombing' the Middle East with books did not alter attitudes toward American policies" (Robbins 648). Acknowledging that the program "might have created some friends in the Muslim world and a market for American books," she nevertheless laments the fact that Americans stopped supporting one bombing for another. Propaganda, warning, and bombs are hardly inspiring words for an engaged scholarship.

\section{Circulation of World Literature through Franklin/Tehran}

As far as our data show, publishing literary works was not a top priority. In both Cairo and Tehran, books of general interest were in demand. In fact, the very first books published with the assistance of Franklin were children's books (the Basic Science Education series by Berta Morris Parker, a 1940 and 1950 s popular series). However, local Franklin men gradually felt the need for literary works, and such books continued to form a considerable portion of the books published. A more special need was also felt as early as 1955 by some Iranian publishers keen on a modern comprehensive "history of world literature" (Sanati, no. 131, July 6, 1955). A final decision on such a title was never made nor was a good book found.

According to Smith (Franklin Book), the total number of books published under Franklin/Tehran was "about eight hundred." The only available list of

propaganda purposes ..." (Al Gamhoria, November 3, 1955). He even took issue with Abbas Al Akkad for his translation and introduction of a book on Benjamin Franklin published by

Franklin/Cairo. 
Fiction

from English

French

Italian

German

originally in Persian

(1)

Juvenile Literature

Poetry

Drama

Total

$\%$ of the total books (787) published from 1954-1975

the books translated into several languages, including Persian (see Franklin Book Program Translated 1952-1970), reports the total number as 850. Further processing of the list shows that Franklin/Tehran published 619 titles from 1954-1970 and 168 from $1970-1975$. If 850 is the definitive total number, then books published from 1975-1978 (the closing year) should be 63, a list of which is still not made.

As Table 1 shows, a considerable number ( $18 \%)$ of works of world literature was produced by a cultural Cold War book program. These works were translated into Persian mainly from English (75), followed by French, Italian and German. The most popular authors in this list include Mark Twain ( 7 titles), Pearl Buck (5), Irving Stone (4), Erich Maria Remarque (4), Jack London (3), Howard Fast (3), William Faulkner (2), Nathaniel Hawthorne (2), William Saroyan (2) and Heinrich Böll (2). Other non-American authors in addition to Böll include I.S. Turgenev (translated from the French Atets i Detii), A. Camus (La Chute), A.A. Chekhov (from the English, The Muzhiks and Other Stories) and L. Pirandello (Uno, Nessuno e centomila), among others.

\section{Negotiation Copyright}

For a work to become part of Franklin's program, securing translation rights was essential. Datus C. Smith, Jr., President of Franklin who in 1953 studied, as part of a survey team, the possibility of opening Franklin offices in the region, 
knew that copyright was not his winning card. He explains Franklin's strategy as follows:

From the beginning, Franklin has tried to encourage the idea of copyrightobservance (a) by insisting on legal acquisition of authorized rights for every book whose translation rights Franklin itself sponsors; (b) by facilitating, where possible, orderly relationships as to translation rights between American properties and the publishers with whom we work in the other countries.

sмiтн Franklin

Overall, Franklin/New York's record in securing translation rights from the American publishers was relatively good, even though some publishers were headstrong, expensive or simply refused to grant rights. For example, despite repeated requests, Ernest Hemingway's literary executor refused to grant permission, and Hemingway was known in Iran and most of the Franklin field offices for a long time only via poor-quality pirated editions and translations. A further example concerns the translation rights of an article by L.A. Coser from Political Sociology: Selected Essays (1966) whose proprietor wanted $\$ 84$ for the right. Writing in response to Cheryl T. Johnson, a Franklin/Tehran chief editor, sympathized with Franklin/New York:

As a matter of principle I should side with you and say to hell with Stein Rokkan's demand for $\$ 84$ for a mere 21 page essay. ${ }^{5}$ Why should we pay four score and four dollars when you can get by with only two score and five? But the truth ... is that we are clearing these rights for a university professor who does not know anything about the delicacy of these negotiations with properties of translation rights. When Franklin is supposed to clear some rights they think it is automatic; you press a button and the proprietor says "by all means".

EMAMI, no. 5786, August 26, 1972, emphasis added

The Iranian editor agreed to pay the requested amount "in the interest of maintaining our reputation for efficiency," however; this was not always the case. Securing rights was indeed more than pressing buttons. It was lengthy

5 The article referred to should be "Prospects for the New Nations: Totalitarianism, Authoritarianism or Democracy," pp. 247-271 in the noted book, which first appeared in Dissent, $\mathrm{x}, 1$ (Winter 1963), pp. 43-58. Rokkan, a Norwegian political scientist, was likely associated with the journal. 
and required extensive communication between Franklin offices with the head office, and the latter with the properties. Sometimes projects in various stages were dropped due to copyright complications, or else changes in political systems in the countries where Franklin was active made financial transfers impossible.

In the context of copyright, Franklin/New York promoted and practiced an ethical discourse. Smith held that "An American publisher who refuses translation rights in the belief that otherwise he would suffer some tiny loss in the profit on his English-language business is doing a great disservice to Asia" (10). Emami was with Smith: "In our experience the introduction of a Persian translation in the Iranian market does not kill off the sales of the original; sometimes it even stimulates such sales" (Emami, no. 5619, January 26, 1972).

Infrastructure problems in New York further complicated Franklin's discourse. According to Byron Buck of Franklin/New York, Franklin was limited to books of us origin because

1. We lack machinery to carry on the bibliographical research necessary in order to make tentative selections of titles from other countries. 2. We are not widely known to the individual publishers in other countries as we are to American publishers, with the result that European and British publishers have been generally reluctant to sell us right to your languages on as favorable terms as American publishers have. 3. Merely from a public relations standpoint we feel that our fundraising from American sources is generally more successful if it is tied to American books.

BUCK, no. 4448, February 26, 1964

Faced with such difficulties, Franklin/Tehran tried to secure rights for French, British and German books, and in this way, the search for rights at an affordable price led to the interesting result that the American program gradually became less American-centered than had been intended. They had some success with French and British publishers, and even considered publishing public domain works to diversify their translation program. For example, Franklin/Tehran reached an agreement with the French publisher Payot for the Persian rights of Charles Werner's, La Philosophie Grecque (1938) for which the publisher would receive "an advance of 500 Francs for the first 5,000 copies of the Persian translation and a royalty of $5 \%$ of the list price thereafter" (Daryabandari, no. 4410, January 21, 1968). These terms seem to be what Franklin/Tehran used in similar cases. 


\section{Local Franklin Men}

Franklin relied on locals to run its program. This included the selection of titles in consultation with Franklin/New York, negotiating with local publishers/authorities, and often responding to local critics (e.g. competing publishers and left-wing activists). Common to any publisher, they shared at least a "dual character" (Bourdieu 138) in the sense of having to run a business and "reconcile art and money".

A good illustration of the role of locals is the selection of titles for translation. Franklin/New York played its part, but the final decision depended on the opinions of the local advisors, editors and having a publisher signed up for the job. For instance, in response to Franklin/Tehran's inquiry about Fitzgerald's The Great Gatsby, Harold H. Munger, Jr., of Franklin/New York, went on to address Homayun Sanati, Franklin/Tehran's director as follows:

Please read the Fitzgerald carefully, for neither Datus, nor Don [Pratt] nor I can think of a single Fitzgerald title that lends itself to translation. By that I mean not even today's teenagers in this country can identify with the way of life, the brief and fleeting days of '2os involving gangsterism, bathtub gin, easy money, marathon parties, and Lord knows what that formed the sum and substance of Fitzgerald's stories. Today his novels seem to lack validity in subject matter, and we in New York are among many who think his writing itself is vastly over-rated.

MUNGER, no. 2537, May 12, 1960

Franklin/Tehran nevertheless persisted, and the translation appeared under the title of Tala va Khakestar (Gold and Ash, 1344/1965). "Over-rated" or not, the locals had a different opinion from their New York peers. ${ }^{6}$ This example is one of the many cases where local interests or values differed from the Americans as regards American novels. Faulkner's works in general and Sanctuary in particular, faced strong opposition from the Franklin/New York (see also Sapiro in this volume).

Who exactly were the locals who ran the Franklin program? Let us look at the noted director of Franklin/Tehran, in office from 1954-1965. As a former affiliate of the leftist party Tudeh, Sanati was young and ambitious, had close ties to intellectuals, and knew influential people. He shared Smith's view that books were essential for a nation's scientific, social and cultural development.

6 By then the book had been hypercannoized in the us. Thanks to David Damrosch for this information. 
He was a man of letters and remained an entrepreneur throughout his life. Writing from Tehran, Smith described Sanati as follows:

Homayun is a wonder-efficient, orderly, and yet highly imaginative. On his toes all the time. At 6:0o p.m. in the evening, we agree that 'sometime' he ought to talk with so-and-so about possible interest in a project, and by 8:0o the next morning he's seen the man and got everything worked out ... he shows no tendency toward penny-pinching in promotion expenses etc., and I must say that the contracts he has negotiated with publishers thus far are astonishingly favorable - the royalty (payable in advance for the whole edition, though by draft with a lapse of one year or so before payable) more or less balancing our visible costs, though of course not office overhead etc.

SMith, no. 3, April 7, 1954

A year later, Dana J. Pratt, observed in Tehran: "this guy Homayun is a promotion-minded publisher if there ever was one .... In the case of this book (Shacter's How Personalities Grow) he sent out 100 complimentary copies to leading Mullahs all over the country. He's now getting back enthusiastic letters, which with their permission, he will reproduce in a circular" (Pratt, July 23, 1955).

In running Franklin/Tehran, Sanati was constantly negotiating possibilities, looking for ways to overcome constraints (e.g. playing a key role in getting funds from the Ford Foundation and the Iranian royal family for the publication of the first Persian encyclopedia, see later). He drew on Franklin's resources and created a wide and generally effective network. He might have been a local man, but his operation and method was anything but local, from getting the best Finnish paper for the publication of Persian classics to the best modern printing equipment from Italy and elsewhere.

Local Franklin directors had to deal with financial issues as well, and Smith's contacts with Sanati is a case in point. For example, with the expansion of the Franklin/Tehran and the publication of books for the Ministry of Education in Iran and later in Afghanistan, Franklin experienced delay in receiving its due payments. Referring to an overdue $\$ 25,000$ for the textbooks mentioned earlier, Smith noted: "We are in serious trouble," and went on to say: "it is vital that the Ministry be made to comprehend the fact that this textbook program is an undertaking that demands full cooperation on all sides .... Has the Ministry reciprocated by doing everything possible to pay its bills on time? Clearly not." (Smith, no. 1121, 4 December 1957). One reason for Sanati to step down from Franklin was financial, that the latter refused to pay off the 
money they had borrowed from Franklin/Tehran (Alinejad), a claim that continues to be investigated.

\section{Impact}

In discussing the impact of the Franklin/Tehran, its history is a good starting point. Reporting in 1974 from the headquarters of Franklin/Tehran, a New York freelancer said that translators working for Franklin/Tehran "translated 757 titles in approximately two and a half million copies for a country of 30 million people, $70 \%$ of them still illiterate." She predicted, "As an upstart national resource, Franklin/Tehran may be more valuable to Iran than its caviar, crown jewels and crude oil" (Yates 115). Less than five years later, Franklin ceased to exist and the Persian crown jewels were handed over to the Revolutionaries who continue to control the declining caviar and crude oil production. In which ways can Franklin/Tehran be "valuable" in a country of about 77 million, of which $85 \%$ are literate, and the average print-run is between 500 to 1,00o copies, less than the print-run during Franklin/Tehran? This is the question that continues to be posed, though the comparison itself starts to make sense.

It would seem that measuring Franklin's impact only in terms of its idealized success or hopeless failure to win hearts or minds misses the gripping story of Franklin in its local manifestations. Its impact can be measured, for example in terms of its contribution to the development of indigenous publishing in the countries where it was operating by introducing modern publishing methods and standards, and creating a more robust translation culture where "book consciousness" (Altbach "Publishing" 5) was on the rise. As a result, those works of world literature circulated in the new contexts entered into a dialogue with local works.

Seen from a global perspective, Franklin's impact on publishing in developing countries was conditioned by low literacy rates, lack of capital, and various governmental policies which more often than not constrained the free flow of information (for a full account, see Franklin Book Programs, Inc; Altbach Publishing). These problems feature throughout the history, policies and practices of Franklin. Smith's A Guide to Book-Publishing (1965) is a collaborative work informed by the way Franklin field offices handled various challenges facing publishing in their countries and the strategies they adopted to overcome them. Franklin also provided an opportunity for training and hands-on experience in publishing. Some early form of what we know today as localization was also common at Franklin local offices. Through "joint press runs" Franklin directors managed to bring out books in different languages within a short period (for details, see Smith "Bright"). 
Franklin's considerable impact in Iran was not accidental. Its opening coincided with Iran's move to becoming a mass consumer society (see Schayegh) and the growing need for literacy and for reading materials for pleasure. With a population of 17.58 million (Bharier 275), the total number of books published in 1950 was only 308 titles per year, rising to 394 titles in 1954 per year (Azarang 251). Out of 850 titles published by Franklin/Tehran, literary works and children's books (each about $18 \%$ ) are at the top of the list, followed by history (17\%), science, including medicine $(15 \%)$, psychology and education $(12 \%)$, Persian and Islamic studies ( $9 \%)$, philosophy $(7 \%)$, and art $(3 \%) .^{7}$

Prior to Franklin/Tehran, there was no wide book distribution system. The establishment of Sherkat-e Ketabha-ye Jibi (the Pocket Book Company) in 1960 aimed to fill the gap. Besides distribution, it succeeded in producing about 500 titles of affordable pocket-size books, which were sold through newsstands and mobile bookracks in the streets of Tehran. It was also through this company that the first model bookshops were introduced into Iran (Figure 1).

Examples of Franklin/Tehran's lasting impact are the Sherkat-e Sahamiye offset (Offset Printing Company), which at the time was "probably the best book plant between Rome and Tokyo" (Smith "Franklin Encouragement" 3), Pars Paper Industrial Group, and the Mosaheb Persian Encyclopedia, the first of its type in Iran, based on a model, which was replicated in Pakistan. Having obtained the translation rights for the Columbia-Viking Desk Encyclopedia, the original plan was to translate the volume cover to cover into several languages. The Persians decided to do otherwise. Having received publishing training in the Us, they adopted a plan in which entries were adapted for the Persian version, new entries originally written in Persian on topics about Iran and Islam were added, and two of the three volumes were published within the Franklin/Tehran program. The production of the encyclopedia in Iran is one of the best achievements of Franklin/Tehran. Several encyclopedia projects in Iran, such as Bonyad-e Danesh-nameh Negari-ye Iran (Iran's Encyclopedia Foundation) are built upon Franklin/Tehran's experience.

In terms of output and dimension, the data suggest that Franklin/Tehran was the most diverse and active Franklin program. From an office of seven people and $\$ 31,291$ in profits in 1954 , it rose to 151 people and $\$ 5,920,612$ in profits for fiscal year 1969/1970 (Mohajer). The financial success of the Franklin/Tehran

7 These data are from Smith ("Franklin Book" 188), though his percentage for "Literature (fiction, essays, verse)" is $19 \%$. 
program enabled it to expand its activities to include the preparation of textbooks for Iranian schools and schools in Afghanistan, the training of Afghanis to work in the publishing industry, the preparation and production of educational materials for students and their parents (e.g. the popular Peyk magazine), just to mention a few. Even Smith could not predict the impact Franklin could have had in Iran: "I think he [Sanati] is completely $100 \%$ wrong in one idea, and yet it does not come from naivete in the normal sense; he sees no reason Franklin cannot be self-supporting in Iran!" Smith was wrong and years later, Franklin/Tehran became financially independent from Franklin (Filstrup 448), the extent of which requires further research.

Franklin/Tehran also employed some of the best minds the nation had to offer. Figures such as political scientist and translator Hamid Enayat (a former member of the leftist party Tudeh) and Persian scholar Gholam Hossein Mossaheb (chief editor for the Persian encyclopedia) took editorial functions, and literary translators such as Emami and Najaf Daryabandari came to work as chief editors. Although it is hard to ascertain whether they shifted away from their political views, they played major roles in selecting and expanding literary works for translation beyond American books and commissioning aspiring translators and editors. Meticulous attention to various stages of editing and the production of books were new endeavours, which were taken seriously at Franklin/Tehran, not to mention developing a copyright ethics by insisting on copyright observance as a pre-condition for such negotiations. Franklin/Tehran even helped an American publishing company to win a legal action against the piracy of their works in Iran (Publishers' Weekly 37). Over the years, final productions of Franklin showed a comparatively better quality than other publications in Persian, attracting publishers to come to Franklin/Tehran to publish their books.

\section{Conclusion: Reading against Propaganda}

Adopting an interdisciplinary approach, this essay has drawn on Franklin archival materials to explore the literary dimensions of a Cold War book program in a non-aligned context during the Cold War.

The discussion of copyright showed that the properties of copyright did not give a blank check to Franklin, simply because it had noble ideals. A compromise had to be found between "propaganda" and market realities, between the piracy of works in many of the areas where Franklin worked and the creation and development of the otherwise capitalist concept of copyright. This compromise and the running of the program had to be done by the local 
Franklin men (that is, the "human capital" as part of the resources needed to run a publishing firm, see Thompson 5) who came to function in different capacities, from selecting titles they saw as suitable for their lists to seeing them through to the final stage of production, distribution and reception. As such, Sanati's practice at Franklin/Tehran begs the simple question of why should a "Cold War warrior," a "propaganda" man go the extra mile for a foreign cause?

Although the propaganda reading of the Franklin Book Programs provides useful background reading, it is not sufficient. In such a reading, there is nothing interesting left to explore, since only two things seem to be at work: the "amalgamation of sentiments and practices" (Travis 197), the good guys and the bad guys, hearts and minds. There is nothing in between, nothing on the same very people who echoed those "sentiments and practices" and turned a "propaganda" foreign program into something more useful, nothing on that transformation, nothing on Franklin's transformation and departure from pure Cold War models over the years, nothing on the extensive knowledge and skills that were transferred and localized, and nothing on the mechanism of title selection. This reading fits well with a reading that did not come from liberal academics, but from post-Revolution ideologues and pre-Revolution Iranian leftist intellectuals who saw Franklin/Tehran as the "executor of Washington's orders" (Allahyari 147) and as the "house of the American spies" (Solhjoo 23) respectively. The Americans packed the propaganda and the local Franklin men blindly distributed it. Really?

Despite its network and a global ideology, Franklin introduced a narrow form of world literature into local cultures. Very few non-English literary works found their way into the recipient cultures. We still do not know how much of this was because of the global position of English, the international flow of books, and the infrastructure problems (see Smith "Two-Way"). Linguistic problems contributed to this imbalance, because, for example, Iran had hardly any translators who could translate from Spanish or Scandinavian languages. It follows that Franklin/Tehran should have welcomed retranslations from English, but our data indicate that aesthetic factors (that is, one translator's dismissal of previous translations) and the copyright ethic played their part in retranslations, as we saw in the case of Hemingway.

The limited form of world literature circulated around the world through Franklin Book Programs requires attention because World Literature has hardly been viewed from a cultural Cold War perspective, let alone from its manifestation in a non-aligned context. World Literature is not only what circulates in translation in a new context under "stable" conditions, it is also what, under "unstable" conditions, is extended and carries tensions with it, in this case, the 
tensions of the superpowers. ${ }^{8}$ This extended world literature has some impact on local literary forms, forms that in retrospect could become world literature.

Looking at Franklin's history from a local point of view, casting a skeptical eye (Siebers) over the cultural history of the Cold War, and empirically measuring its impact, less biased insights can be gleaned on the cultural Cold War in a non-aligned context and its weight in the circulation of books and world literature. Thus, we need collaborative work in the form of research group(s) with team members representing countries where Franklin had field offices. ${ }^{9}$

\section{Acknowledgment}

This article has benefited from comments received from David Damrosch, Susan Bassnett, Omid Azadibougar, and two anonymous reviewers of the JWL, hence my thanks. I should also mention two reviewers of the journal Target who commented on a very different version and the Harry Ransom Center for their Humanities Fellowship in 2015 that allowed me to stay at the Center for a second time to collect data and permission to reproduce figure 1 .

\section{Works Cited}

\section{Primary Resources}

"Franklin Book Program Collection, 1952-1978." The Harry Ransom Center (HRC), University of Texas at Austin.

Numbers in brackets refer to box numbers: Buck, 4448 (34); Daryabandari, 4410 (37); el-Aroussy, 408, translated quotes from Al Gamhoria (27); Emami, 5619, 5786 (39); Munger, 2537 (32); Pratt, July 23, 1955 (33); Sanati, F. 24, 131 (34); Smith, 1121 (32); 3, 298, 6138 (33); 4359 (34). Franklin Certificate of Incorporation; the promotional

8 I am building on Odd Arne Westad, who in discussing the political aspect of Cold War in the Third World, argues that many Third World countries became victims "through the extension of Cold War tensions to their territories" (561). True to some extent, I am more with Chubin ("Iran" 218) in arguing that although the Cold War was "a period of fluctuating insecurity for Iran, but it was not without its benefits."

9 In addition to HRC, Franklin archives are in two places. First, the Library of Congress holds the "Franklin Book Program Collection: Archival set of Franklin Program publications of American books translated into Middle Eastern and Asian languages." Second, the Princeton University Library holds the "Franklin Book Programs Records" available at the Department of Rare Books and Special Collections. 
material Franklin Book Programs Inc., 1976; and the "memorandum" entitled "Not for publications — staff use only": (40).

\section{Secondary Resources}

Alinejad, Cyrus. "Goftegu ba Homayun Sanati darbareh-ye shekl giri-ye entesharat-e Franklin (Interview with Homayun Sanati on the Formation of Franklin Publishing)." ввC Persian. 14 Aug. 2008. Web. 20 Dec. 2015.

Allahyari, Ahmad. Revayat-e Sansur: Momayyezi va Sansur dar Asr-e Pahlavi (The Story of Censorship in the Pahlavi Period). Tehran: Keyhan, 1387/2008.

Altbach, Philip G. "Publishing and the Intellectual System." Annals, AAPss 421 (1975), $1-13$.

Altbach, Philip G. Publishing and Development in the Third World. Oxford: Hans Zell, 1992.

Alvandi, Roham. Nixon, Kissinger, and the Shah: The United States and Iran in the Cold War. Oxford: Oxford UP, 2014.

Azarang, Abdolhossein. Mabani-ye Nashr-e Ketab (An Introduction to Book Publishing). Tehran: Samt, 2007.

Barnhisel, Greg, and Catherine Turner, eds. Pressing the Fight: Print, Propaganda, and the Cold War. Massachusetts: University of Massachusetts Press, 2010.

Barnhisel, Greg. "Cold Warriors of the Book: American Book Programs in the 1950s." Book History 13 (2010), 185-217.

Barnhisel, Greg. Cold War Modernists: Art, Literature, and American Cultural Diplomacy. New York: Columbia UP, 2015.

Baumgarten, Stefan. "Ideology and Translation." Handbook of Translation Studies. Vol. 3 , ed. Yves Gambier and Luc Van Doorslaer. Amsterdam: Benjamins, 2010, 60-65.

Berghahn, Volker R. America and Intellectual Cold Wars in Europe: Shepard Stone between Philanthropy, Academy and Diplomacy. Princeton: Princeton UP, 2001.

Bharier, J. "A Note on the Population of Iran, 1900-1966." Population Studies: A Journal of Demography 22: 2 (1968), 273-279.

Bourdieu, Pierre. "A Conservative Revolution in Publishing." Trans. R. Fraser. Translation Studies 1: 2 (2008), 123-153.

Buzelin, Hélène. “Agents of Translation.” In Handbook of Translation Studies. Vol. 2, ed. Yves Gambier and Luc Van Doorslaer. Amsterdam: Benjamins, 2010, 6-12.

Casanova, Pascale. The World Republic of Letters. Trans. M.B. DeBevoise. Cambridge, MA: Harvard UP, 2004.

Chubin, Shahram. "Iran." In The Cold War and the Middle East, ed. Yezid Sayigh and Avi Shlaim. Oxford: Oxford UP, 1997, 216-249.

Cull, Nicholas J. The Cold War and the United States Information Agency: American Propaganda and Public Diplomacy, 1945-1989. Cambridge: Cambridge UP, 2008.

D'haen, Theo. The Routledge Concise History of World Literature. London and New York: Routledge, 2012. 
Filstrup, J.M. “Franklin Book Program/Tehran.” International Library Review 8 (1976), 431-450.

Franklin Book Programs, Inc. Books for Developing Countries: A Guide for the Enlisting Private-Industry Assistance. Prepared for the United States Agency for International Development. New York: Franklin, 1969.

Franklin Book Program Books Translated 1952-1970. Web. 10 May 2014.

Hixon, Walter L. Parting the Curtain: Propaganda, Culture, and the Cold War, 1945-1961. New York: St Martin's Press, 1997.

Iber, Patrick. Neither Peace nor Freedom: The Cultural Cold War in Latin America. Harvard UP, 2016.

Krabbendam, Hans, and Giles Scott-Smith. eds. The Cultural Cold War in Western Europe, 1945-6o. London: Routledge, 2004.

Laugesen, Amanda. "Books for the World: American Book Programs in the Developing World, 1948-1968." In Pressing the Fight: Print, Propaganda, and the Cold War, ed. Greg Barnhisel and Catherine Turnel. Massachusetts: University of Massachusetts Press, 2010, 126-144.

Loss, Christopher P. "Reading between Enemy Lines: Armed Services Editions and World War II." The Journal of Military Service 67 (2003), 811-34.

Masey, Jack, and Conway Lloyd Morgan. Cold War Confrontations. Us Exhibitions and Their Role in the Cultural Cold War. Zürich: Lars Müller, 2008.

Milton, John, and Paul Bandia, eds. Agents of Translation. Amsterdam: Benjamins, 2009. Mohajer, Ali Asghar. “Tehran/Iran." In Newsletter: Franklin Book Program, March 1971, no. 45. Franklin Book Program Collection, 1952-1978. Box 40, Harry Ransom Center, University of Texas at Austin.

Moretti, Franco. “Conjectures on World Literature." In Debating World Literature, ed. Christopher Prendergast. London: Verso, 2004, 148-162.

Ninkovich, Frank A. The Diplomacy of Ideas: Us Foreign Policy and Cultural Relations, 1938-1950. Cambridge: Cambridge UP, 1981.

Philips, Matthew. Thailand in the Cold War. London and New York: Routledge, 2016.

Publishers' Weekly. "American Company Wins Piracy Suit in Iran.” 6 Dec. 1965: 37.

Robbins, Louise. S. "Publishing American Values: The Franklin Book Programs as Cold War Cultural Diplomacy." Library Trends 55: 3 (2007), 638-650.

Sapiro, Gisèle. "How do Literary Works Cross Borders (Or Not)? A Sociological Approach to World Literature." Journal of World Literature 1: 1 (2016), 81-96.

Saunders, Frances Stoner. The Cultural Cold War: The CIA and the World of Arts and Letters. New York, NY: The New Press, 1999.

Sayigh, Yezid, and Avi Shlaim, eds. The Cold War and the Middle East. Oxford: Oxford UP, 1997 .

Schayegh, Cyrus. "Iran's Karaj Dam Affair: Emerging Mass Consumerism, the Politics of Promise, and the Cold War in the Third World." Comparative Studies in Society and History 54: 3 (2012), 612-643. 
Siebers, Tobin. Cold War Criticism and the Politics of Skepticism. New York: NY, Oxford, 1993.

Solhjoo, Ali. "Goftegu ba Ali Solhjoo (An Interview with Ali Solhjoo)." Motarjem 9: 33 (1379/2000), 19-44.

Smith, Datus C. "Franklin Encouragement of Copyright Observance." Franklin Book Program Collection, 1952-1978. Box 40, Harry Ransom Center, University of Texas at Austin.

Smith, Datus C. A Guide to Book Publishing. Seattle, wA: University of Washington Press, 1965 .

Smith, Datus C. "The Bright Promise of Publishing in Developing Countries." The American Academy of Political and Social Science 421 (1975), 130-139.

Smith, Datus C. "The Two-Way Flow of Information between East and West: Obstacles and Solutions." In The International Flow of Information: A Trans-Pacific Perspective, ed. John Y. Cole. Washington: Library of Congress, 1981, 18-20.

Smith, Datus C. "Franklin Book Program." In Encyclopcedia Iranica. Vol. X, ed. Ehsan Yarshater, 2000, 187-190.

Thompson, John B. Merchants of Culture: The Publishing Business in the Twenty-First Century. Cambridge-Malden: Polity Press, 2010.

Thomsen, Mads Rosendahl. Mapping World Literature: International Canonization and Transnational Literatures. London: Continuum, 2008.

Travis, Trysh. "Books in the Cold War: Beyond 'Culture' and 'Information'." In The Oxford Handbook of Propaganda Studies, ed. Jonathan Auerbach and Russ Castronovo, Oxford: Oxford UP, 2013, 180-200.

$\mathrm{Vu}$, Tuong and W. Wongsurawat. Dynamics of the Cold War in Asia: Ideology, Identity, and Culture. New York: Palgrave, 2009.

Westad, Odd Arne. "The New International History of the Cold War: Three (Possible) Paradigms." Diplomatic History 24: 4 (2000), 551-565.

Wulf, Andfrew James. U.s. International Exhibitions during the Cold War: Winning Hearts and Minds through Cultural Diplomacy. Lanham, Md: Rowman \& Littlefield, 2015 .

Yates, Maya. "Bringing Books to Iran." Publishers' Weekly 23 Sep. 1974: 114-117. 